\title{
Legislative instruments and their use in the management of raw materials in the Slovak Republic
}

\author{
Lucia BEDNÁROVÁ1 *, Jana DŽUKOVÁ ${ }^{2}$, Roland GROSOS ${ }^{3}$, Marián GOMORY \\ and Miloš PETRÁS $\check{S}^{5}$
}

Authors' affiliations and addresses:

${ }^{I}$ Faculty of Mining, Ecology, Process Control and Geotechnologies Technical University of Kosice, PK 19, 04200 Košice, Slovak Republic e-mail: lucia.bednarova@tuke.sk

${ }^{2}$ Faculty of Mining, Ecology, Process Control and Geotechnologies Technical University of Kosice, PK 19, 04200 Košice, Slovak Republic e-mail: janka.dzukova@gmail.com

${ }^{3}$ Faculty of Mining, Ecology, Process Control and Geotechnologies Technical University of Kosice, PK 19, 04200 Košice, Slovak Republic e-mail: roland.grosos@tuke.sk

${ }^{4}$ Faculty of Mining, Ecology, Process Control and Geotechnologies Technical University of Kosice, PK 19, 04200 Košice, Slovak Republic e-mail: marian.gomory@tuke.sk

${ }^{5}$ Faculty of Mining, Ecology, Process Control and Geotechnologies Technical University of Kosice, PK 19, 04200 Košice, Slovak Republic e-mail: milos.petras@tuke.sk

*Correspondence:

Lucia Bednárová, Faculty of Mining, Ecology, Process Control and Geotechnologies Technical University of Kosice, PK 19, 04200 Košice, Slovak Republic

tel: +421903357959

e-mail: lucia.bednarova@tuke.sk:

\section{Acknowledgement:}

This paper was supported by the Scientific Grant Agency od the Ministry of Education of Slovak republic under grant VEGA 1/0651/2018 - Research of institutional environment influence to the corporate social responsibility, consumers satisfaction and performance of the company.

\section{How to cite this article:}

Bednárová, L., Džuková, J., Grosoš, R., Gomory, M. and Petráš, M. (2020). Legislative instruments and their use in the management of raw materials in the Slovak Republic. Acta Montanistica Slovaca, Volume 25 (1), 105-115

DOI:

https://doi.org/10.46544/AMS.v25i1.10

\begin{abstract}
Mineral resources are an integral part of society's life and affect many sectors of society's economy. None of the production sectors of the economy and social life can exist without securing a sufficient amount of minerals. In this article, we deal with the analysis of the raw materials policy of the Slovak Republic. A necessary condition for the creation of the raw material policy of the territory is the knowledge of the raw material base and the raw material needs of the given territory. Without this knowledge, raw materials policy-making is impossible. We made an analysis of the legal environment on the basis of which we created a set of critical areas of the Slovak Republic raw materials policy. We have drafted a recommendation to be incorporated into the legislative proposals with regard to raw materials policy. The proposed recommendation could ensure the sustainability of the country's mining industry as well as streamlining mining fees.
\end{abstract}

\section{Keywords}

raw material policy, mining, legislative, mining fee.

(C) 2020 by the authors. Submitted for possible open access publication under the terms and conditions of the Creative Commons Attribution (CC BY) license (http://creativecommons.org/licenses/by/4.0/). 


\section{Introduction}

Global change and especially the global environmental crisis pose a serious challenge to the available control systems, including the legal system. We already know what has to be done: the demand for an "effective state" and for "effective low" is the central axis around which political and administrative reform must be attempted in our age. The law that has adopted the new, systemic decision-making methods has been put forward as the most flexible.

Raw materials are essential for the sustainable functioning of modern societies. Access to and affordability of mineral raw materials are crucial for the sound functioning of the EU's economy. Sectors such as construction, chemicals, automotive, aerospace, machinery and equipment sectors which provide a total value added of $€ 1$ 324 billion and employment for some 30 million people all depend on access to raw materials.

The starting point of this article is the need to implement the Raw Materials Initiative, in particular its second pillar, which relates to fostering a sustainable supply of raw materials within the European Union from domestic resources. This is also taking place in the framework of the implementation phase of the Strategic Implementation Plan (SIP) of the European Innovation Partnership on Raw Materials. The latter plan identifies a number of particular actions, under Action areas "II.1 Minerals Policy Framework"; and "II.2 Access to Mineral Potential in the EU", which relate to the challenges of "policy and legal framework, information framework, land-use planning and permitting".

Action area "II.1 Minerals Policy Framework" aims to "strengthen the exchange of best practices in the area of mineral policies and related regulation among the Member States, that may lead to streamlining the permitting procedure along the whole chain of extractive activities (prospecting, exploration, extraction, processing, closure, post-closure activities) with regard to the time frame, the regulatory co-authority regime, the financial and administrative conditions, and ensure stable, predictive environment." "Another objective is to increase transparency on raw materials availability in the EU ( Straka et al., 2016). Information on exploration, mineral production, trade, reserves and resources should be standardized and systematically reported by the EU and the Members States, when information is available and without breaching competition rules."

The goal of raw material policy should be to define priorities for Slovakian raw material industry from the view of the need to provide sustainable development of national economy and society, as well as to define measurements and tools for providing of stable development of single raw material industry and its competitiveness in international level in the measure, adequate to created conditions (Cavender, 1992). The goal of the presented contribution is, therefore, to make a system for raw material legislative policy in particular conditions of the country. The larger the system, the greater the number of factors, decisions, constraints, and risks it involves (Straka et al., 2018). Knowledge of these factors is very important not only for the development of relevant policy concepts in the country but also for the national and international benchmarking (Khouri et al., 2017).

The mineral wealth of the Slovak Republic is the property of the state, and thus the state itself allows the use of this wealth to individual organizations, which are obliged to pay fees for this use if the specified legal conditions are met. The legislative framework for the use of the state's mineral wealth is determined by laws, decrees, government regulations and other generally legally binding acts. Mineral wealth is exploited in many industries, and some industries would not exist without minerals. Strategic intentions and directions in the use of the state's mineral wealth are defined in the Raw Materials Policy, from which subsequent generally binding legal acts should be derived. These strategic intentions need to be updated on the basis of geopolitical developments but also on the basis of scientific and technical progress, new knowledge and other factors.

The role of the state is to protect mineral wealth, but also to create suitable conditions for its rational use.

\section{Literature review}

Many countries in the world run their economies with minerals in various forms, be it mining, importing or exporting minerals. The more developed a country is the more it uses modern raw materials and materials, which until recently were considered unnecessary waste, and the less the country has its own resources of minerals, the more important it is for it to approach the raw materials policy. One of the important criteria in formulating rules and principles on securing the country with minerals is the maturity of the country.

Today we know full well that, for example, it is clearly futile to monitor the cleanliness of the atmosphere, waters and soils, if you do not at the same time curb those who pollute them. There must at least be understanding of the simple systemic rule "think globally and act locally", which is addressed to every responsible citizen in our age and stresses the interdependence of the many factors that stem from man's intervention in the environment (Bednárová et al., 2018). However, the decision-makers must also recognize that sustainable development, which imposes the incorporation of criteria for the protection of natural, cultural and social capital in every policy whether public or private, is nothing more than the necessary and delayed application of systemic thinking in making decisions of all kinds. However, although that is how things stand in 
the new science of sustainable development, the same need to implement systemic methodology also exists for the Law of Sustainable Development (Decleris, 2000).

The mining industry can be critical to a nation's economic well-being. Impacts may be felt on a national or regional level, with their significance dependent in part on the resources under development as well as existing government policies. The changing character of mining is today opening up new opportunities for foreign investment and technology assistance (Dorian et al., 1994).

Mining activities divide communities and countries (Gray, 2018) due to different geological, legislation, political, social, and economic conditions. Therefore, analysis of mining activities must be regarded from the view of the growth economy, encouraged by government tools - together with ecological integrity (Gentry\&Neil, 1984).

Openness, transparency, and public participation of the state is a longstanding issue. The state must adopt such decision to public participation with the aim to prevent mining activities from harmful impact to environment, society, and economy. Therefore, also in areas of mining principles of corporate, social responsibility must be regarded (Curran, 2017).

The new Circular Economy package contains a combination of both legislative and non-legislative elements, such as new and revised legislative proposals on waste, clear targets for waste reduction - such as the common EU target for recycling 65 per cent of municipal waste by 2030 - and proposed actions to "close the loop" and tackle all phases in the lifecycle of a product: from production and consumption to waste management and the market for secondary raw materials. It also contains a list of proposed actions that will target market barriers in specific sectors or material streams, such as critical raw materials, as well as horizontal measures in the areas of innovation and investment.

Critical Raw Materials have also been identified as a priority area in the new package. According to the European Commission, existing EU legislation encourages the recycling of electronic waste, including through mandatory targets; but only high-quality recycling can ensure the recovery of critical raw materials. As a result, the EU is focusing on improving the economic viability of the recycling process and encouraging member states to promote the recycling of critical raw materials in its revised proposals on waste. As a result, the Commission is taking a series of actions to encourage the recovery of critical raw materials, including producing a report on best practices and options for further action mention in critical raw materials from 2018.

Developed countries use different strategies to meet the needs of minerals. On the one hand, it is a slowdown in the extraction of domestic resources and a significant import of minerals, in order to ensure the needs of the country in the event of poorer availability of resources. On the other hand, it is mutually beneficial international cooperation, which includes: geological exploration, and mining in a developing country, and the establishment of joint enterprises for the processing of minerals, including the training and employment of workers in developing countries. Japan is one example of this strategy, which it has been pursuing for a long time and successfully.

The efficient use of domestic mineral resources is interfered with by internal and external factors. Internal factors interfere with the quality and volume of proven geological reserves, the maturity of the industrial infrastructure in the mining zone, the mining conditions. External factors that interfere with the usability of domestic mineral resources are mainly based on the liberalization of the market for commodities of mineral origin, world market prices. Also, in terms of availability and contingency, offset them from a domestic source, including secondary raw materials. From the point of view of socio-political intentions declared in the Constitution of the Slovak Republic and the course of integration into the EU, raw materials policy must seriously have the social and ecological focus of market policy in mining and processing of minerals, it also takes into account the careful use of natural resources. The EU's dependence on imports of energy minerals is highly critical, where the EU's dependence on imports is up to $54 \%$.

Based on this, it is absolutely crucial to:

- diversify sources of supply of energy commodities, especially from the point of view of suppliers,

- reduce energy intensity in all spheres of life,

- increase the share of the use of renewable energy sources (biomass, wind, water, sun),

- save their own energy resources (41 regions in $13 \mathrm{EU}$ countries mine coal),

- support the search for new deposits of mineral energy commodities (uranium, shale gas),

- support science and research in the development of new types of fuels (hydrogen and others).

The current legislation should be replaced after consultation of individual regions and strengthened national responsibility, as well as the encouragement of information exchange between countries. Relations present various supplier-consumer, legislative, property, personal, economic, political, and other relations in the frame of the system, as well as relations with its surroundings. System of "Slovakian raw material industry" presents a subset in the vertical level of European and worldwide raw material industry. In horizontal level, it presents part of the Slovakian national economy. 


\section{Methodology}

Minerals policies are sometimes not clear and effective enough because they are either dispersed among other policies or have no public and implementation support. Coordination and implementation of minerals policies at different levels (EU, Member States regional, local) and horizontally with other sectorial policies is often not straightforward and therefore, in some cases, contradictory and time-consuming.

Even in the cases where Member States (MS) have recently issued a modern minerals policy strategy, adapted to the needs of society and the economy, this could prove to be ineffective if this policy is not strongly linked with other national policies such as an appropriate land use planning policy, environment policy including biodiversity and mine waste management and also with a common understanding and categorization of mineral deposits of local, regional, national and EU importance.

Legislation should facilitate innovation. Competition is vital to the flourishing industry in Europe and should remain a top priority. In addition, it must be ensured that competition law allows the establishment and development of research partnerships.

Policy and legislative processes need to underpin the competitiveness of industry when it comes to access to and trading in raw materials, by means of harmonization and bottom-up orientation. A cumulative impact assessment, which evaluates the impact of multiple policies, should form the basis for a comprehensive EU industrial policy which coordinates the individual policies and ensures a level playing field. This will only be possible with a consolidated vision across Europe, and a clear understanding of the needs and capacities of each member state and region, as well as the synergies they bring to the EU's internal market. This might require more institutionalized consultation processes with the European Economic and Social Committee (EESC) mention in Strategic implementation plan for the European innovation partnership on raw materials.

The raw materials policy deals not only with renewable resources but also with fuel, energy, ore and nonore and construction raw materials from primary as well as secondary sources. Secondary resources form an important part of raw materials policy, not only in terms of saving primary resources but also in terms of saving costs and energy for the treatment and processing of primary raw materials. It follows that raw materials policy is not only directly linked to energy policy but is closely linked to it. Few countries have so many types of minerals to cover their domestic consumption, so they are dependent on imports. Conversely, many countries are dependent on the export of minerals to other countries, whether raw or already processed. Therefore, an integral part of raw materials policy is the issue of import and export of minerals.

The environmental activities are carried out in the legislative frameworks, which also create a platform for setting up regulatory and stabilization mechanisms in the area of environmental, economic and social policies. Our goal is to harmonize the legislation of the Slovak Republic and propose changes in the case of direct payments from mining in the most affected areas. In many permitting procedure segments, especially at the local/regional level, qualified personnel may be missing or be insufficiently trained. Transparency regarding the permitting procedures as well as the level of permitting fees, royalties, etc., is not always sufficient. The permitting procedure would be enhanced if the EU mineral potential were considered in the design of national mineral and land use planning policies. Rational use of mineral wealth means that we will allow applicants to use mineral wealth in accordance with laws and regulations, permits and restrictions that will be defined, during the permitting process. Rational means reasonable, i.e., so that everyone can benefit from this process. State in the form of fees and taxes, employees in the form of wages for work performed, employers in the form of profits. Customers who obtain primary raw materials for their purposes. Intervention into the rock environment must be thoughtful, systematic, the most modern methods and approaches must be used to make the intervention as considerate as possible. The state should support such use of mineral wealth, i.e. it must create such conditions that mineral wealth can be used rationally.

There are several examples where rational use can be spoken of only partially or not at all. From the systematic view, there is possible to consider the Slovakian raw material industry as a single system. Elements of the system present all research, mining, processing, metallurgical, recycling, education, environmental organizations, as well as state and administration institutions. Relations present various supplier consumer, legislative, property, personal, economic, political, and other relations in the frame of the system, as well as relations with its surroundings. The classification of the sectors was based on the SK NACE Rev. 2, which represents the classification used in the conditions of the Slovak Republic, formerly referred to as OKEC (Sectoral Classification of Economic Activities). According to this classification, we have selected sector mining and quarrying for our use. For further processing of economic parameters, we performed a financial analysis within selected companies as well as an analysis of financial flows, on the basis of which we can compile an overview of fees for mining space.

In the contribution, we will deal with the description of individual system elements interests, for example, miners, applicators of raw materials, consumers, environmentalists, politicians, etc. However, from the systematic point of view, there is necessary to underline that all such interests together present one set of interest that has its very complex structure, in which some interests contradict each other, others are in antagonistic 
relation, some have only objective or only subjective characteristics, some are short term or long-term, resp. permanently applied.

\section{Results}

\section{Payments for the use of earth resources in Slovak republic compering the other V4 countries}

A major problem at the legislative level is the various authorization procedures, which are lengthy in time and the information required for authorizations is ambiguous. The permitting procedure is often lengthy and involves many authorities with potentially overlapping and even conflicting requirements. Thus, the whole permitting chain sometimes does not have a clear course since various, and sometimes repetitive requirements are requested based on different pieces of legislation. Some of the required information is frequently not available to investors at the time of permit application on the one hand, and on the other permit applications frequently lack the required information, which should be provided by investors.

In the case of Slovak legislation, we deal with several problems. Each organization that has a designated mining area is, according to par. 32a of Act 44/1988 Coll. Mining Act, as amended, obliged to pay a fee for the mining area. The fee is 663.88 EUR for each $\mathrm{km}^{2}$ started. As mentioned before, $20 \%$ of the fee is the revenue of the state budget, and $80 \%$ is the revenue of the municipality or municipalities in whose cadastral territories the relevant mining area is located.

Another fee is the fee from the extracted mineral. The method of calculation as well as the fee rate is determined by Government Regulation 50/2002 Coll. on payment for mining area, payment for extracted minerals and on payment for storage of gases or liquids. Reimbursement for extracted minerals is calculated for each quarter of the calendar year as the product of the ratio of the costs of mining the minerals to the total costs of making products from the extracted minerals, revenues from sold products made from the extracted minerals and the reimbursement rate. What we need to mention is, so the payment is the income of the Environmental Fund.

The obligation to pay compensation for extracted mineral has been in our legal system since 1991. If we compare the system of fees for extracted mineral with neighbouring countries, we will find that the system is the same in the Czech Republic. Rates are higher, for some minerals up to several times. However, the system of fees in Hungary is different and is based on determining the value of extracted mineral (Government Regulation) and the percentage rate, which is $5 \%$ for surface mining, if we compare these fees with fees in the Slovak Republic, we find that for some commodities fees are several times higher as in SR. In the Polish system, however, there is a significant difference in the fact that in the Geological and Mining Act, the rate of the fee is directly determined, and the fee is the product of the extracted amount of mineral and the rate of the fee. However, what is also different is who is the recipient of this fee. The distribution of the fee according to the recipients is given in Tab. 1 .

Table. 1. Distribution of fees according to V4 countries

\begin{tabular}{|c|c|c|}
\hline State & \% payment share & Recipient of charge \\
\hline Slovak Republic & $100 \%$ & Environmental fund \\
\hline \multirow{2}{*}{ Czech Republic } & $25 \%$ & National budget \\
\cline { 2 - 3 } & $75 \%$ & Municipality according to the cadaster of the mining area \\
\hline Hungary & $100 \%$ & Office of Mining and Geology \\
\hline \multirow{2}{*}{ Poland } & $40 \%$ & National fund for environmental protection \\
\cline { 2 - 3 } & $60 \%$ & Municipality according to the cadaster of the mining area \\
\hline
\end{tabular}

source: XV. Odborný seminár SZVK; Zborník prednášok str. 31 - 42; Atrium hotel, Nový Smokovec 42; Vysoké Tatry; 24. - 25.10.2013

It follows from the above that the recipient is the state only in Hungary and Slovakia. In Slovakia, the fees are the lowest. The highest share, up to $75 \%$ of the fee for extracted mineral, will be obtained by the municipality in which the mining area (MA) in the Czech Republic is located. In this context, it is important to say that the immediate environment is in the immediate vicinity of mineral extraction. These loads are mainly noise, dust, vibration, soil and water pollution as well as loads caused by traffic services. However, as for direct payments in the Slovak Republic, the municipality in which the mining area (MA) is located will receive only $80 \%$ of the fee for the mining area, which is in most cases 531.10 EUR / year, because most of the mining area has a size of up to $1 \mathrm{~km} 2$. Tab. 19 presents the distribution of recipients of fees for mining space and extracted mineral in selected DPs of the company LBK PERLIT, Ltd. and LB MINERALS SK, Ltd. for 2017. 
Table .2. distribution of fees LB MINERALS SK, Ltd. and LBK PERLIT, Ltd.

\begin{tabular}{|c|c|c|c|c|c|c|}
\hline Mining area & Comp & $\begin{array}{c}\text { any } \\
\text { Payment for } \\
\text { MA }\end{array}$ & $\begin{array}{c}\text { Fees for } \\
\text { extracted } \\
\text { mineral }\end{array}$ & Total fee & Village & State \\
\hline \multirow{2}{*}{$\begin{array}{l}\text { Lehôtka pod } \\
\text { Brehmi }\end{array}$} & \multirow{2}{*}{$\begin{array}{l}\text { LBK PERLIT, } \\
\text { Ltd. }\end{array}$} & \multirow{2}{*}{$664 €$} & \multirow{2}{*}{$7045 €$} & \multirow{2}{*}{$7709 €$} & $531 €$ & $7178 €$ \\
\hline & & & & & $7 \%$ & $93 \%$ \\
\hline \multirow{2}{*}{ Šaštín } & \multirow{2}{*}{$\begin{array}{c}\text { LB } \\
\text { MINERALS } \\
\text { SK, Ltd. }\end{array}$} & \multirow{2}{*}{$1328 €$} & \multirow{2}{*}{$6223 €$} & \multirow{2}{*}{$7551 €$} & $1062 €$ & $6489 €$ \\
\hline & & & & & $14 \%$ & $86 \%$ \\
\hline \multirow{2}{*}{ Tomášovce } & \multirow{2}{*}{$\begin{array}{c}\text { LB } \\
\text { MINERALS } \\
\text { SK, Ltd. }\end{array}$} & \multirow{2}{*}{$664 €$} & \multirow{2}{*}{$5014 €$} & \multirow{2}{*}{$5678 €$} & $531 €$ & $5147 €$ \\
\hline & & & & & $9 \%$ & $91 \%$ \\
\hline \multirow{2}{*}{ Rudník } & \multirow{2}{*}{$\begin{array}{c}\text { LB } \\
\text { MINERALS } \\
\text { SK, Ltd. }\end{array}$} & \multirow{2}{*}{$664 €$} & \multirow{2}{*}{$8377 €$} & \multirow{2}{*}{$9041 €$} & $531 €$ & $8510 €$ \\
\hline & & & & & $6 \%$ & $94 \%$ \\
\hline \multirow{2}{*}{ Rudník II } & \multirow{2}{*}{$\begin{array}{c}\text { LB } \\
\text { MINERALS } \\
\text { SK, Ltd. }\end{array}$} & \multirow{2}{*}{$664 €$} & \multirow{2}{*}{$2155 €$} & \multirow{2}{*}{$2819 €$} & $531 €$ & $2288 €$ \\
\hline & & & & & $19 \%$ & $81 \%$ \\
\hline \multirow{2}{*}{ Michal'any } & \multirow{2}{*}{$\begin{array}{c}\text { LB } \\
\text { MINERALS } \\
\text { SK, Ltd. }\end{array}$} & \multirow{2}{*}{$664 €$} & \multirow{2}{*}{$14245 €$} & \multirow{2}{*}{$14909 €$} & $531 €$ & $14378 €$ \\
\hline & & & & & $4 \%$ & $96 \%$ \\
\hline \multirow{2}{*}{ Ťahanovce } & \multirow{2}{*}{$\begin{array}{c}\text { LB } \\
\text { MINERALS } \\
\text { SK, Ltd. }\end{array}$} & \multirow{2}{*}{$664 €$} & \multirow{2}{*}{$2304 €$} & \multirow{2}{*}{$2968 €$} & $531 €$ & $2437 €$ \\
\hline & & & & & $8 \%$ & $82 \%$ \\
\hline
\end{tabular}

source: LB MINERALS SK, Ltd., LBK PERLIT, Ltd. (Mendel, 2019)

As can be seen from Table 2, the distribution of income from fees for mining activities is divided so that the municipality that bears the most burdens due to mining activities, obtains by direct payments from fees from $4 \%$ in the case of MA Michal'any to $19 \%$ in the case of MA Rudník II. Paradoxically, the more the mining company benefits, the relatively lower the share of direct payments from fees for the municipality. System set up in this way the distribution of income from payments for mining activities appears to be unfair and makes it significantly more difficult for mining companies to negotiate in the mining licensing process. Municipalities usually no longer agree with mining activities. Why should they also, when $100 \%$ of negative consequences are borne by municipalities, but they have from $4 \%$ to $19 \%$ of the fees in the case of the MAs listed in the table. The municipality, as a participant in the procedure for a mining activity permit, mostly on the basis of requests from citizens, proposes various measures to eliminate these negative impacts, which are many times intractable or difficult to solve and highly costly. They propose restrictions on production and transport service time, construction of bypass roads, prohibition or restriction of blasting works, various environmental measures even beyond the relevant laws. Mining companies, on the other hand, try to eliminate these negative consequences of mining activities with various concessions or services for the benefit of the municipality. We believe that the state in politics charges is failing and should change this policy. A municipality that is affected by mining activities must feel that, in order to bear these negative consequences, they have advantages that distinguish them from other municipalities, for example, lower taxes, free transport, free kindergarten, a significantly higher share of fees for mining activities and others. They must be positively discriminated against compared to other municipalities that do not feel these negative consequences of mining activities.

\section{The position of the mining industry in Slovak society}

The extractive industry occupies a special position among industries, as it provides raw materials for other industries. So, in that industrial chain, the industry is at the very beginning. Only metallurgy has a similar special position from the point of view of industries, i.e., metallurgical primary production, which is in the second place in the chain. The importance of the extractive industry is assessed from two basic perspectives:

- economic - its share in the gross domestic product,

- nation economic.

No extractive industry can be characterized only in terms of economic inputs and outputs, because the extractive industry requires significant investment inputs and produces outputs with very low added value $(0$ added value) (Mendel, 2019). It serves primarily as a supporting type of industry for other downstream industries. The share of the value of mining is very low in individual countries in relation to gross domestic product. Globally, this ratio is around 5\%. In different European countries, this share of value manifests itself differently and depends on the value of mining in a given country and the structure of industries. The position of 
the mining industry in comparison with other industrial and industrial areas in the Slovak Republic is shown in Table 3.

Table.3. SK NACE rev. 2 - selected indicators 2016

\begin{tabular}{|c|c|c|c|c|}
\hline \multirow{2}{*}{ SK NACE } & \multicolumn{2}{|c|}{ Gross production } & \multicolumn{2}{|c|}{ Employment } \\
\hline & mil. EUR & $\%$ & number & $\%$ \\
\hline Sum & 197075,7 & 100 & 2321049 & 100 \\
\hline Mining and quarrying & 535,6 & 0,27 & 6525 & 0,28 \\
\hline Manufacturing & 76640,3 & 38,89 & 508814 & 21,92 \\
\hline Construction & 14646,6 & 7,43 & 166132 & 7,16 \\
\hline Other & 105253 & 53,41 & 1639578 & 70,64 \\
\hline
\end{tabular}

source: own processing form SK NACE selected information

As shown by the data in Table 3, mining and quarrying are of only marginal importance for the national economy of the Slovak Republic in terms of GDP and employment. This can also be attributed to the low political influence in negotiations with partners, as well as the weak enforcement of bills that would protect or support the extraction and processing of minerals. For example, 134,483 employees work in healthcare (21 times more than in mining and quarrying) or 171,875 employees in education (26 times more than in mining and quarrying). However, we dare say that these statistics (SK NACE rev 2.) have certain shortcomings and inaccuracies in terms of interpreting the share of mining and quarrying in total gross output as well as employment. For example, the production of cement, lime, concrete or magnesite is carried out under industry and not undermining and quarrying, which can significantly distort these statistics to the detriment of mining and quarrying.

Mining and quarrying are closely linked to other industries such as the chemical industry, the petrochemical industry, the energy industry, the rubber industry, the metallurgical industry, the construction industry, the automotive industry, the glass and ceramics industry, but also the electrical engineering industry. Without the minerals that are the inputs to these industries, these industries could not exist. What would it mean for the Slovak economy if we immediately stopped mining, for example, building materials such as gravel, sand or building stone, or non-metallic raw materials such as limestone (cement and lime production) and we would be completely dependent on the import of these raw materials from abroad. The prices of these commodities would become several times more expensive because the price of these commodities would be significantly affected by the purchase price but especially the transport of these commodities. $30 € / \mathrm{t}$. This increase would be reflected in the price of building stone products such as concrete, mortar or bituminous mixtures, and this, in turn, would affect the realizable price of the buildings. There would also be a deterioration of the environment, which would be enormously burdened by increased traffic, there would be more significant wear and tear on the transport infrastructure, which we would have to rehabilitate from public resources. This means that the mining industry is much more important for the economy and life of the Slovak Republic than is presented in the statistical data. It is certainly necessary to think about redefining the minerals for which fees are levied. Many mining activities, in particular gravel mining or building stone mining, which are not reserved for minerals but have a high environmental impact on the environment, should also be included among the minerals for which fees will be paid. On the one hand, a certain injustice would be eliminated, whereas, for strategic reasons, certain deposits of building stone or gravel have been classified as reserved deposits. Regarding the number of fees, as mentioned above, in comparison with neighbouring countries, the fees in Slovakia are lower and a certain adjustment upwards, in the event that the redistribution of recipients of fees is adjusted, such as, for example, in the Czech Republic, would certainly improve the permitting process for mining activities. The calculation of the fee for the extracted mineral, which gives room for certain creativity of accountants in mining companies, is also questionable, and the state mining administration, which controls these calculations, does not have enough professionally qualified inspectors to detect these tricks. The fee system in place in Poland or Hungary is certainly clearer and less sensitive to manipulation by mining companies.

\section{Raw material security and rational use of mineral wealth}

The role of the state is not only to protect the mineral deposit but should create the conditions for such deposits not to be speculatively blocked because then the state loses the benefits that it could obtain by actively using such deposits. Application of the concept of mineral deposits of public importance as to facilitate investment in similar way as for hydrocarbons but ensuring that mineral property rights are sufficiently protected. Slovakia is also relatively well geologically researched in comparison with the most developed countries in the world, and we do not expect to discover any deposit of world importance here. But the occurrences of some elements, which were included among the critical elements defined by the EC, we could 
find here. In the past, these elements were not as important as they are today and were considered a pollutant rather than a useful mineral. Today, geological exploration is funded almost exclusively from private sources, but many investors are discouraged by the unstable legislative environment. Some changes in the law affect the significance of the results of geological work. As an example, we can mention the already mentioned Kuríšková deposit or the gold deposit near Detva or Kremnica. We are of the opinion that the state, as the owner of mineral wealth, should care to have thorough information about mineral wealth and how it could benefit from it. The state should finance the geological survey from the state budget. The survey should focus on those critical raw materials defined by the EC. It should certainly be invested in a survey focused on the use of energy in the earth's core, where the Slovak Republic has great and hitherto untapped potential. All the above information has one common denominator, and thus there is insufficient legislation in the field of mining activities as well as fees associated with it. The update of the raw materials policy as of 31 December 2003 and the evaluation of the fulfilment of the objectives of this update as of 31 December 2018, i.e., after 15 years, brought conclusions that lead to the following conclusions.

The main objectives of the raw materials policy were the following:

- Liberalization and organization of the mineral market

Status: In 2003, there were no market barriers to the sale of mineral commodities.

- Coordination of the use of minerals in terms of their lifespan

Status: There is no legislation coordinating the use of minerals for their lifetime.

- Sustainable development of the company while at the same time the efficient use of domestic resources of mineral resources

Status: Declarative task, not implemented in any legislation.

- Reassessment of the methodology for classifying mineral resources according to the UN methodology.

Condition: Not implemented.

- Evaluation of mineral deposits, so-called feasibility study before their use, which will determine the value of the deposit for the investor as well as the state.

Condition: Not implemented.

- Stabilization of the workforce in regions with developed mining.

Status: Declarative task.

- Attenuation programs for unpromising mining industries.

Status: No attenuation program was adopted after 31.12.2003. A decline in mining activity and liquidation of the Baňa Dolina a.s.Vel'ký Krtíš (Government Resolution No. 1037/2001).

This evaluation of the main objectives of raw materials policy (as amended in 2003) shows that the objectives have not been met after 15 years. The objectives of the raw materials policy did not reach the implementation and realization through generally legally binding acts of the Slovak Republic. This suggests that such an understanding of raw materials policy is vague and legally ineffective. Raw materials policy is rather just an academic work that has no or almost no impact on minerals in the Slovak Republic. Even some of the measures that have been taken are at odds with raw materials policy, such as radioactive minerals. There is no mention of radioactive minerals in the raw materials policy or in its 2003 update. Nevertheless, an amendment to the Geological Act was adopted in 2013, where paragraph 24 a) was inserted. Unless raw materials policy becomes an integral part of the legal system of the state, its creation or updating is only an academic work, which has only a marginal influence on the real activity of the state, mining companies and the public. We dare say that whether or not we have a raw materials policy will not change in reality. In no legal Act of the Slovak Republic is the phrase Raw materials policy, no legal regulation refers to raw materials policy. In the Czech Republic, the Mining Act is in the comment procedure, which will directly refer to the raw materials policy. Such anchoring of our raw materials policy would certainly increase the seriousness of such a work, and politicians could no longer ignore it as it is now.

As we have already stated in the previous points, the last update of the raw materials policy is from 2004 as of 31.12.2003. This means that for 15 years no update has been made, resp. issued a new raw materials policy. This condition is definitely incorrect and has several reasons. Greater efforts were expected by the Ministry of Economy of the Slovak Republic, which is the creator and guarantor of previous raw materials policies. It was probably not enough political will to act more forcefully in this matter, which is certainly caused by the weak political influence of the miners, resp. excessive influence of conservation associations. Indeed, there could be a real risk that the raw materials policy, as part of the inter-ministerial commentary, would be subject to measures that would not be aimed at protecting and promoting the use of raw materials. Greater efforts should also be made by the professional public; if the state is not active in this matter, then the initiative should be taken by the one who is least satisfied with this situation. There are several professional organizations such as the Slovak Mining Company, the Slovak Association of Aggregate Producers or the Association of Metallurgy, Mining and Geology, which have the support of mining in Slovakia in their statutes. We also had stronger expectations from the academic community, which knew this situation and have enough experts to create a raw materials policy 
model. Table 4 contains findings that are, in our view, critical for the raw materials policy of the Slovak Republic and the EU. Since we most areas in previous paragraphs devoted in the table to individual findings, adding the draft measures to eliminate the negative impact on the investigated area. We consider the solution of these areas to be key within the solution of the issue of mineral resources in the Slovak Republic. We are of the opinion that if these findings are not satisfactorily addressed, the situation with regard to minerals will not improve; on the contrary, the situation will worsen. Of these areas, we consider the following to be absolutely most important

- fees,

- energy raw materials.

If the fee policy does not change, the company's view on mining and mineral processing will not change either. Both the Slovak Republic and the EU have a high and even poorly diversified import dependence on energy minerals, which could have fatal consequences for our and the EU economy in the event of geopolitical tensions.

Table. 4. Critical areas of the raw materials policy of the Slovak Republic

\begin{tabular}{|c|c|c|}
\hline Area & Detection & Proposal for measures \\
\hline Binding nature of the raw material policy & $\begin{array}{l}\text { The raw materials policy is not enshrined } \\
\text { in any legally binding one document of } \\
\text { the Slovak Republic if we do not consider } \\
\text { the Resolution to be legally binding of the } \\
\text { Government of the SR. Experience as } \\
\text { shown that such legal force is for binding. } \\
\text { Insufficient raw materials DO lies. }\end{array}$ & $\begin{array}{l}\text { Secure the raw materials policy in the legal order of } \\
\text { the Slovak Republic, for example, in the Mining Act, } \\
\text { which would refer to the Raw Materials Policy. }\end{array}$ \\
\hline Raw materials policy update & $\begin{array}{l}\text { The raw materials policy has not been } \\
\text { updated since } 2003 \text {. }\end{array}$ & $\begin{array}{l}\text { Continuous updating of the raw material policy as } \\
\text { proposed by the National technology platform for } \\
\text { research, development and innovation in the field } \\
\text { minerals. Strategic goals they must have such legal } \\
\text { force that they change will only be subject to broad } \\
\text { society-wide professional discussion. To avoid } \\
\text { frequent changes strategic objectives of the raw } \\
\text { material policy, we propose its approval in parliament } \\
\text { by a constitutional majority. }\end{array}$ \\
\hline $\begin{array}{l}\text { The long - term sustainable raw materials } \\
\text { policy }\end{array}$ & $\begin{array}{c}\text { Change in the laws that concerned } \\
\text { minerals such as gold or radioactive } \\
\text { minerals are not consistent with the } \\
\text { current one raw materials policy. Laws } \\
\text { protecting the environment they make it } \\
\text { difficult but impossible to all objectives of } \\
\text { raw materials policy. }\end{array}$ & $\begin{array}{l}\text { To prepare a wide society discussion on the consensus } \\
\text { between the use of the raw material potential of the } \\
\text { state and environmental protection. Establish the } \\
\text { agreement in the legislation of the state. }\end{array}$ \\
\hline Energy resources & $\begin{array}{l}\text { Currently, except the coal, there are } \\
\text { almost no usable energy sources in } \\
\text { Slovakia. Geothermal energy is a one of } \\
\text { possible source, but under current } \\
\text { conditions it has no legislative support or } \\
\text { its use is hindered by trade agreements. }\end{array}$ & $\begin{array}{l}\text { Reduce import dependence on energy raw materials } \\
\text { by support renewable energy sources as well as } \\
\text { rational use of their own raw- material resources such } \\
\text { as uranium or geothermal energy. Brown coal as the } \\
\text { only one currently in existence to protect the raw- } \\
\text { material energy source as a strategic reserve. }\end{array}$ \\
\hline Fee & $\begin{array}{c}\text { Present policy fees settings for the use of } \\
\text { the mineral wealth of the Slovak Republic } \\
\text { is not optimal. From point of view of the } \\
\text { negative consequences, which mining, } \\
\text { processing, transportation serviceability } \\
\text { during mining and processing minerals } \\
\text { brings, are very low. }\end{array}$ & $\begin{array}{c}\text { Simplify usage calculation mineral wealth and } \\
\text { eliminate a differentiated approach to reserved and } \\
\text { non-reserved the mineral. Amount of fees for mining } \\
\text { areas as well as for extracted minerals is too low to be } \\
\text { a more significant resource income. Recipients of fees } \\
\text { should be above all those who are mining, and } \\
\text { processing of minerals and with it associated traffic } \\
\text { load, noise and dust loads and other negative factors } \\
\text { the most load. }\end{array}$ \\
\hline $\begin{array}{l}\text { The position of the mining industry in } \\
\text { society }\end{array}$ & $\begin{array}{c}\text { The mining industry consists only } \\
\text { negligible share in the GDP of the Slovak } \\
\text { Republic. However, the importance of raw } \\
\text { materials as a primary source for } \\
\text { industries is underestimated. The public } \\
\text { considers it their natural right to have } \\
\text { access to raw materials. The problem is } \\
\text { that they do not even think about the } \\
\text { impact of mineral extraction on the } \\
\text { environment. }\end{array}$ & $\begin{array}{l}\text { It is essential to raise awareness to laic public } \\
\text { about the importance of minerals for everyday life in } \\
\text { modern society. How would the abandonment of the } \\
\text { use of minerals affect the lives of every inhabitant of } \\
\text { the Slovak Republic or the EU. }\end{array}$ \\
\hline
\end{tabular}




\begin{tabular}{|c|c|c|}
\hline Rational use of mineral resources & $\begin{array}{c}\text { The state protects mineral wealth through } \\
\text { the Institute of Protected Deposit territory } \\
\text { and the Mining Area. The state does not } \\
\text { create an enough stable legislative } \\
\text { environment for investors, which would } \\
\text { be able invest to the geological survey. } \\
\text { The state does not have effective tools to } \\
\text { take away mining areas to organizations, } \\
\text { which block them from speculative } \\
\text { reasons. }\end{array}$ & $\begin{array}{l}\text { The state should not only protect minerals wealth but } \\
\text { also create appropriate conditions so that we can use } \\
\text { mineral wealth rationally, of which would benefit all } \\
\text { involved social groups. The state should invest } \mathrm{m} \\
\text { your own geological survey to have knowledge of } \\
\text { raw- materials potentials that he would know then } \\
\text { appropriately and in line with strategic interests of the } \\
\text { Slovak Republic. }\end{array}$ \\
\hline
\end{tabular}

source: own processing

\section{Conclusion}

Raw materials policy must be a general consensus among all stakeholders involved in its creation. It must be a compromise between environmental protection and the need to secure minerals for the proper functioning of the state. The state, the people of the state and all participants in this process must benefit from this process. The safest access (safe raw materials) is to the raw materials that we can find in our territory, they are of sufficient quality, and we have enough of them. In the conditions of the Slovak Republic, limestone, dolomite, magnesite and building materials can certainly be considered safe minerals. The most dangerous (critical) approach is to raw materials that we do not have, but they are necessary for the functioning of society, and without these raw materials, we could not exist. In the conditions of the Slovak Republic, it can be said with certainty that all energy raw materials such as oil, natural gas, coal or uranium can be considered as these. The Slovak Republic is very vulnerable in terms of the need for these raw materials, without which life in Slovakia would have stopped and due to the fact that we import almost all these raw materials from Russia. Any political tension can cause the cessation of these supplies, and the Slovak Republic would, in the long run, find it very difficult to find a replacement for these supplies. By application of new legislative, we should also improve the transparency of information on raw materials through public reporting. This will allow prudent use of existing and future mineral deposits, as well as former mining site to be re-opened if appropriate and to contribute to developing monitoring systems on raw materials, flows and early warning systems on EU dependency on certain raw materials.

\section{References}

Aktualizácia surovinovej politiky SR; MH SR, http://www.economy.gov.sk/surovinova-politika-5672/127357s

Bednárová, L., Chovancová, J., Pacana, A., Ulewicz, R. (2018). The Analysis of Success Factors in Terms of Adaptation of Expatriates to Work in International Organizations. - Registrovaný: Web of Science, Registrovaný: Scopus. In PolishJournal of Management Studie. - Czestochowa : Faculty of Management, CzestochowaUniversity of Technology. ISSN 2081-7452, 2018, vol. 17, no. 1, pp. 59-66

Bednárová, L. et al. The Life cycle assessment of selected production in SimanPro V.7. - Registrovaný: Web of Science. In Geoconference on ecology, economics, education and legislation SGEM 2014. international multidisciplinary scientific geoconference. Geoconference on ecology, economics, education and legislation SGEM 2014: 14th international multidisciplinary scientific geoconference, 17-26 june 2014, Albena, Bulgaria. - Sofia: STEF92 Technology Ltd., 2014. ISBN 978-619-7105-19-3, pp. 479-484.

Cavender, B. (1992). Determination of the optimum lifetime of a mining project using discounted cash-flow and option pricing techniques. Mining Engineering, New York, 1992

Communication from the Commission to the European parliament, the council the European economic and social committee and the committee of the regions tackling the challenges in commodity markets and raw material, Brussels, 2.2.2011, Retrieved from https://eur-lex.europa.eu/legalcontent/SK/TXT/HTML/?uri=CELEX:52011DC0025\&from=EN

Critical raw materials, Critical Raw Materials Alliance c/o Ridens Public Affairs | Rue Belliard 40, 1040, September 2018, Brussels, Retrieved from https://www.crmalliance.eu/circular-economy-environment

Colving, R.M., Witt, G.B., Lacey, J. (2015) The social identity approach to understanding socio-political conflict in environmental and natural resources management. Global Environmental Change, vol. 34, p. 237-246

Decleris, M. (2000). The law of sustainable development, General priciples, Luxembourg: Office for Official Publications of the European Communities, 2000 ISBN 92-828-9287-5https://www.pikpotsdam.de/avec/peyresq2003/talks/0917/sillence/background_literature/sustlaw.pdf

Dorian. J.P., Humphreys, H.B. (1994). Economic impacts of mining A changing role in the transitional economies, https://doi.org/10.1111/j.1477-8947.1994.tb00869.x

Gentry, D.W., O’Neil, T.J. (1984). Mine Investment analysis. Soc. of Min. Engineers of. Am. Inst. of Min., Metall., and Petroleum Engineers. New York 1984, p. 502 
Gray, J. (2018). A global update on the ambit of unconventional gasmining and analternative framework for mediating energy demands. Ecological Integrity, Law and Governance, p. 119-128.

Grincova, A., Andrejiova, M., Marasova, D., Khouri, S. (2019). Measurement and determination of the absorbed impact energy for conveyor belts of various structures under impact loading, Volume: 131, Pages: 362371, DOI: 10.1016/j.measurement.2018.09.003, JAN 2019

Hajduová, Z., Lacko, R., Mildeová, S., Stričík, M. (2015) Case study in the field of innovation in selected companies in Slovak Republic. In: Scientific annals of the Alexandru Ioan Cuza University of Iasi: Economic sciences. - Poland : De Gruyter, 2015. ISSN 2068-8717, vol. 62, no. 1, pp. 103-199 online.

Jurkasova, Z., Cehlar, M., Khouri, S. (2016). Tools for organizational changes managing in companies with high qualified employees, Pages: 409-412, CRC PRESS-TAYLOR \& FRANCIS GROUP, 6000 BROKEN SOUND PARKWAY NW, STE 300, BOCA RATON, FL 33487-2742 USA,

Khouri, S., Cehlar, M., Horansky, K., Sandorova, K. (2017). Expected life expectancy and its determinants in selected European countries. Transformation in Business and Economics, vol.16, No 2B, p. 638-655.

Kúšik, D., Mižák, J., Šoltes, S. (2017). Nerastné suroviny SR. Slovak minerals yearbook 2017; (C Štátny geologický ústav Dionýza Štúra 2018. ISBN 978-80-8174-037-4

Mendel, J., (2019): Stratégia využívania zemských zdrojov SR z pohl’adu Surovinovej politiky EÚ v rámci,

Dissertation thesis

Natura (2000). Legislation. Available at: http://www.sopsr.sk/natura/index1.php?p=3\&lang=sk

Pelaudeix, C., Basse, E.M., Loukacheva, N. (2017) Openness, transparency and public participation in the governance of uranium mining in Greenland: A legal and political track record. Polar Record, vol.53, No 6, p. 603-616.

Pickett, S. and McDonnell, M. (2017). The art and science of writing a publishable article. Journal of Urban Ecology, 3(1).

Rybár, P, Cehlár, M., Engel, J., Mihok, J. (2005) Evaluation of mineral deposits, AMS, FBERG, TU Košice, 2005

Straka, M., Lenort, R., Khouri, S., Feliks, J. (2018). Design of large-scale logistics systems using computer simulation hierarchic structure. International Journal of Simulation Modelling, vol.17, No 1, p.105-118

Straka, M., Cehlar, M., Khouri, S., Trebuna, P., Rosova, A., Malindzakova, M. (2016). Asbestos exposure and minimization of risks at its disposal by applying the principles of logistics, Przemysl Chemiczny in 2016. vol 95., issue 5, p.n963-970doi.org/10.15199/62.2016.5.13

Šimková, Z., Očenášová, M., Tudoš, D., Róth, B. (2019). The political frame of the European Union formining of non-energetic raw materials, Acta Montanistica Slovaca Volume 24, number 1, 35-43 ISSN 1335-1788

Surovinová politika ČR v oblasti nerostných surovin a jejich zdroju, Ministerstvo průmyslu a obchodu ČR; http://www.ospzv-aso.cz/addons/114\%20RHSD/2014-11-21-Surovinova-politika.pdf

Strategic implementation plan for the European innovation partnership on raw materials, part II -priority areas, action area and actions 18/09/2013 Retrieved from https://ec.europa.eu/growth/sites/growth/files/eip-sippart-2.pdf

Strategic Dialogue on Sustainable Raw Materials for Europe, STRADE November 2018, Retrieved from https://www.stradeproject.eu/index.php?id=3

Study on the review of the list of critical raw materials. Critical raw materials facts sheets. Written by deloitte sustainability, British geological survey, Bureau de rechercheséologigues et miniéres, Netherlands organization for applied scientific research, June 2017; ISBN 978-92-79-72119-9. (C) EÚropeanUnion

Trade, Growth and World Affairs: Trade Policy as a Core Component of the EU's 2020 Strategy; European

Commission, 2010, 8

Zimon, D., Gajewska, T., Bednarová, L. (2016). An Influence of quality management system for improvement of logistics distribution. - Registrovaný: Scopus. In Quality - Access to Success. - Bucharest: Society for Quality Assurance - SRAC, 2016. ISSN 1582-2559, 2016, vol. 17, no. 155, pp. 60-672017

XV. Odborný seminár SZVK; Zborník prednášok; str. 31 - 42; Atrium hotel, Nový Smokovec 42; Vysoké Tatry; 24. -25.10 .2013$ 